\title{
NATM の設計プログラムの開発 \\ DESIGN PROGRAM FOR A NEW TUNNELING METHOD USEING BOLTS AND SHOTCRETE
}

土 屋敬*

By Takashi TSUCHIYA

\begin{abstract}
A computer program was developed to design a new tunneling method using bolts and shotcrete, so-called NATM.

Combined effect of the bolts to reinforce the tunnel ground comes from reaction caused by ground displacement and maintenance of the three-demensional stress condition of ground which prevents the ground deterioration. Analysis is executed step by step with progress of excavation. Progressive deformation with stope advance is calculated using the creep function. Bolts will slide, if the axial force exceeds the shear resistance between bolt and ground. Proper model can be chosen to represent a specific case of shotcrete depending on the design objective. A slit in the shotcrete to be provided in a tunnel subjected to heavy deformation can also be modeled.
\end{abstract}

\section{1. まえがき}

近年, 新しいトンネル工法として, ロックボルトと吹 付けコンクリートを主体とした NATM が意欲的に導入 されつつある. 本工法は主としてオーストリアを中心と するヨーロッパにおいて発展しつつあったが，いまだ ロックボルトの支保原理等について研究段階であり, し たがって，設計法について明確なものは示されていな かった。そこでこの導入にあたり著者らは, 基本から取 り組むこととし，ロックボルトの支保原理に関するブ ロック実験"1, トンネル模型実験 ${ }^{2}$ 等を行い, 併行して 設計プログラムの開発を行ってきた。これまで本プログ ラムについてすでに2 3 の発表 ${ }^{3)}$ (4)を行ったが，その後 も数次の改良を加えてきており，このたび一応の決着を みたと考えられるのでとりまとめて発表する.

\section{2. プログラムの機能の概要}

プログラムは設計および現場計測管理に対し，必要十 分な情報を与え得る機能を有するものであることを目標 とする. それらの機能を列挙すると,

i）地山および支保部材の粘弾塑性的材料特性を適

* 正会員 国鉄鉄道技術研究所構造物研究室主任研究員 ( 185 国分寺市光町 2-8-36)
切に表現し得ること。

ii）ロックボルトおよび吹付けコンクリートの支保 効果を十分現わし得ること.

iii）ロックボルトの滑りの有無を判定し得ること.

iv）ロックボルトにプレストレスを与え得ること.

V） 薄肉要素である覆工の適切なモデル化.

vi）覆工の可縮スリットのモデル化.

vii）変位，応力等が経時的に計算し得ること.

Viii）トンネルの段階的な施工の状態を表現し得るこ と.

ix）切羽による三次元的な支保効果を表現し得るこ と.

x）地山の安定度を評価し得ること。

これらを満足するものとして基本的には非線形弾性 $F E M$ を用いる，FEM は二次元平面ひずみによるが切 羽の進行に伴う三次元的ひずみは擬似的にクリープ関数 を利用して計算する。

\section{3. 地山の物性}

ロックボルトによって補強されたモルタルブロックを トンネル側壁の一部とみなした載荷実験において（図一 1)，最大約 9 倍の補強効果が観察されたが，この効果は ロックボルトの三軸的地山拘束効果によって説明するこ 

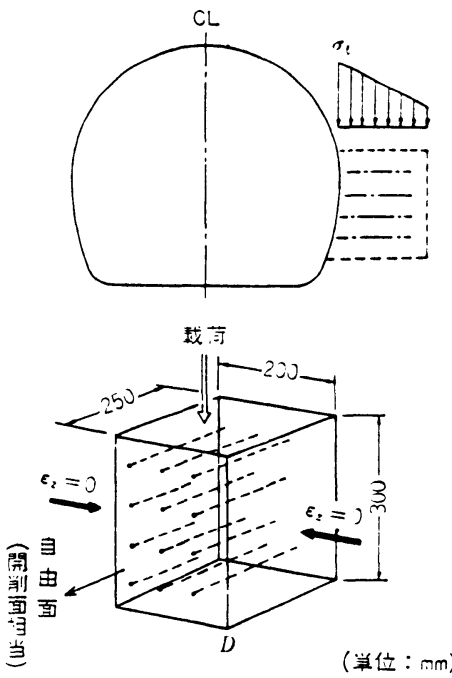

図一1 ブロック実験の概念図

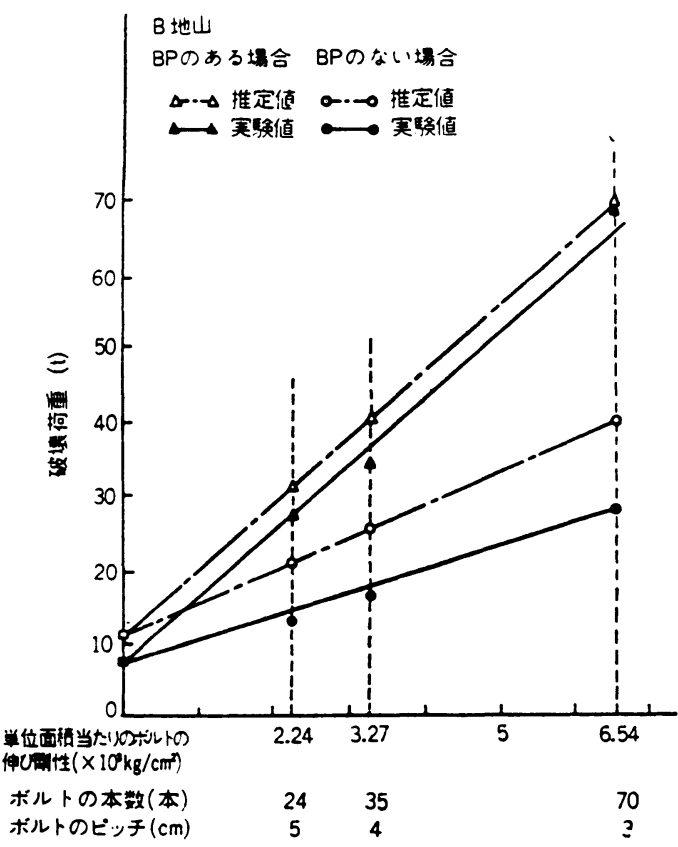

図一2 ブロック試噱におけるボルトの地山捕強奻果

とができだ!.図一2はロックボルトの数量と破壊荷重 との関係を示し，ロックボルト数量の増加とともに破壊 強度が増加していることがわかる.図における推定値は, あらかじめ行った三軸試験結果を利用し，ベアリングプ レート (図中 BP と表示) ありの場合はボルトの破断 強度から, ベアリングプレートなしの場合は引抜試験に おける強度から三軸拘束圧 $\sigma_{3}$ を計算し, それに見合う $\sigma_{1}$ を算出したものである. 推定值は試験結果とよく一 致しており, ロックボルトによる補強原理を十分説明し
得たと考えられる.

このような補強効果を設計プログラム上で表現するた めには，三軸拘束圧によって変化する非線形な地山材料 特性を導入する必要がある．本プログラムでは下記の 4 つの非線形モデルを備えている.

A. 破壊接近度による表現

B. Duncan の双曲線式による表現

C. バイリニア法による表現

D. トライリニア法による表現

これらのうち，Aを主として用いてきた，当初，こ れを用いた理由は電中研等ですでに用いられ，各種岩盤 について比較的資料が得られやすいと判断したためであ $3^{51.6)}$. 現在大型トンネル試験装置を用い模型実験を実 施中であり, 試験結果を各種の非線形モデルを用いた解 析值と比較しているが, 軟岩, 未固結地山を対象とした 場合この手法が比較的よい一致を示している.

この手法は主応力円とモールクーロンの破壊条件との 相対的接近度より, 図一-3の記号により破壊接近度 $R$ を式（1）で定義し， $R$ を助変数として地山の物性值 を与えようとするものである.

$$
R=\min \left(d_{1} / D_{1}, d_{2} / D_{2}\right)
$$

$R$ は 0 から 1 の間で変化し, 1 のとき最も安定, 0 のと きは破壊である， $R$ が 1 から 0 まで変化する間に変形 係数を連続的に娍少させ，ポアソン比は連続的に増大さ せる.その後，NATMで施工されたいくつかのトンネ ルの岩石試験結果を調查したところ, 未固結地山では上 述のように $R$ が 1 から減少すると，ただちに変形係数 は減少し始めるが, 硬岩地山等では変形係数の変化しな い破壊接近度の範囲がみられる。これを弾性との境界の 意味で $R_{E L}$ と呼ぶこととする. $R$ を $R_{E L}$ との関係で式 (2)により $R^{\prime}$ に置き換え, 式 (3), (4)で变形係数, ポアソン比と関係づける.
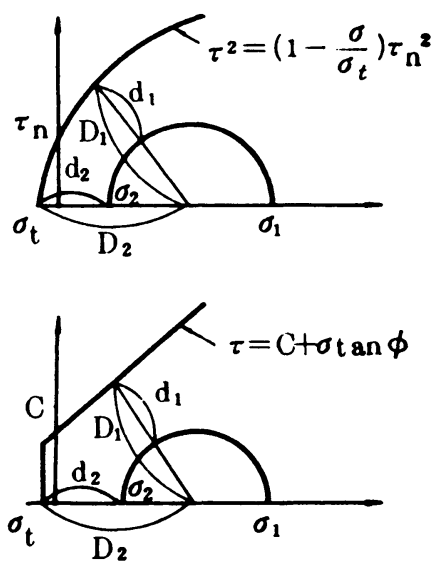

図一3 破塔包絡袙と応力図 


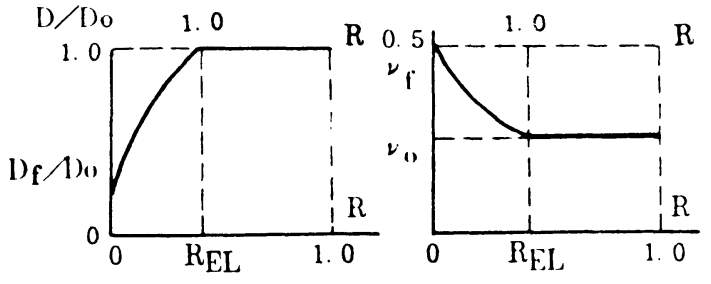

图一4破培接近度と变形係数，ポアソン比の関係

$$
\begin{aligned}
& R^{\prime}=1 \quad\left(R \geqq R_{E L}\right) \\
& R^{\prime}=R / R_{E L} \quad\left(R<R_{E L}\right) \\
& D / D_{o}=R^{\prime \frac{1}{n}}+\left(1-R^{\prime \frac{1}{n}}\right) D_{J} / D_{o} \\
& \nu=\nu_{0} R^{\prime \frac{1}{m}}+\left(1-R^{\prime \frac{1}{m}}\right)_{\nu_{s}}
\end{aligned}
$$

ここに， $D_{o}, \nu_{0}$ ：最も安定した状態における変形係数

$$
\text { とポアンン比 }
$$

$D_{s}, \nu_{s}$ : 破壊時における值

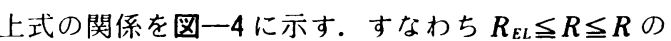
範囲では地山は弾性的に挙動し, $R<R_{E L}$ の範囲では式 （2）で置き直した $R^{\prime}$ が 1 から 0 まで変化する間に変 形係数 $D$ は健全な $D_{0}$ から減少して $D$ ，になりポアンン 比は $\nu_{o}$ から增大して $\nu_{f}$ に変化する， $n$ は $R^{\prime}$ に対する $D$ の変化の仕方の経路のバラメーターである．kは一般 に2であると報告されている7.

\section{4. ロックボルト}

地山とロックボルトの間の定着力が不足する場合に ロックボルトが滑ると考えられるので，ロックボルトの モデル化において滑り判定機能をもたせた。このため, ロックボルトはロッド要素と特殊結合要素の組合せによ り表現する．ロックボルトと岩の結合状態を表わすのに 特殊結合要素 (ばね要素) の剛性を応力の状態により恋 化させて評価する，すなわち堅固に結合されているとみ なせる状態では $K=\infty$ (実際にはロックボルトの軸方向 剛性に比較して十分大きな有限の值）とし，滑っている とみなせる状態では 0 （０に近い值）にする.

滑りの判定には, 個々の結合要素ごとにロックボルト および岩盤に対する支配幅を決め，その区間内における 岩盤の平均垂直応力 $\bar{\sigma}_{n}$ と, 結合要素の節点における左 右のロックボルトの軸力の差 $T$, より判定を行う.すな わちボルトの軸力差 $T_{j}$ が節点 $j$ を滑らそうとする力で あり，これが $\bar{\sigma}_{n}$ から定めるこの区間の引抜き耐力より

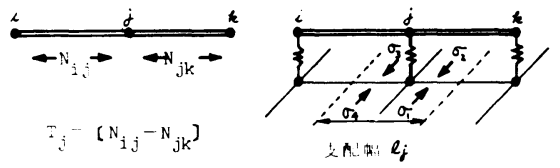

图一5 ロックボルトの軸差カと締付けカ
小さければ堅合に結合されているものとする.

ロックボルトの表面は異型処理がなされ付着性はよい ので一般に滑り面はモルタルと地山の境界で発生する. 境界でのせん断抵抗は

$$
\begin{aligned}
& \tau_{r}=c+\bar{\sigma}_{n} \tan \phi \\
& \text { ここに, } c: \text { : 地山と充填材との間の粘着力 }
\end{aligned}
$$

$$
\phi: \text { 地山と充媜材との間の摩擦角 }
$$

$\bar{\sigma}_{n}=\left(\sigma_{1}+\sigma_{2}+\sigma_{3}+\sigma_{4}\right) / 4$

$c, \phi は$ 地山または充填材の弱い方の物性值で決定され

る. $\bar{\sigma}_{n}$ はロックボルト打設後の增加応力を取らなけれ ばならない，ただし膨張性充填材を用いてストレスを加 えることができる場合には $\bar{\sigma}_{n}$ は大きく取ることができ るであろう.

これより引抜き耐力は

$$
\begin{aligned}
R_{j}=2 \pi r l_{j} \cdot \tau_{r} & =2 \pi r l_{j}\left(c+\bar{\sigma}_{n} \tan \phi\right) \\
r & : \text { 孔径 }(\text { モルタル径 }) \\
l_{s} & : \text { 支配幅 }
\end{aligned}
$$

ロックボルトの節点 $j$ における軸差力 $T$, がこの点にお ける引抜き耐力 $R$ ，を超えると，その節点でロックボル トと節点は滑るものとして特殊結合要素の剛性 $K_{j}$ を 0 とする.

ボルトの材料特性としてはねじり棒鋼に対する非線形 弾性特性亡普通棒鋼に対する完全弾塑性特性のいずれか を撰択し得る。

また，ロックボルトには外力としてプレストレスを与 えることができる.

\section{5. 吹付けコンクリート}

\section{（1）吹付けコンクリートのモデル化}

通常吹付けコンクリートは薄肉であるから, 曲げモー メントには対抗できず, クラックの発生は許容すべきも のとし, 両端ヒンジのロッド要素によっている. 両端ヒ ンジの部材であってもアーチ構造で地山から反力を受け るため, 一般には安定である. ロッド要素とすると構造 的不安定々なる特別の場合にはビーム要素または格子枠 要素を用いる.

A. ロッド要素

両端ヒンジの棒鋼造でありモーメントは計算し得な い. しかし覆工は本来アーチの性格が強い構造形をして おり, 主として軸力により対抗するのでロット要素とし て解析しても大きな誤差を生じない場合が多い. 円形に 近い断面形で全断面掘削する場合などはこれに該当す る.また吹付けコンクリートはきわめて薄肉でしかも掘 削直後に施工され大変形を受けるのでクラックを発生 し，ヒンジ的になるので，実態はこのケースに近いよう にも考えられる.

B. ビーム要素 
軸力とモーメントの両者を計算し得る最も単純な要素 としてはビーム要素がある.

C. 格子枠要素

これは二次覆工等の比較的厚肉の部材を表現するのに 適するもので図一6に示す 6 本の棒で構成される. 棒の 断面積 $A_{a}, A_{c}$ は覆工と軸剛性および曲げ剛性を等しく する条件により求められる. ロッドの断面積を適当に選

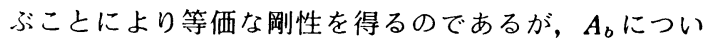
ては次のように考えられる. 格子枠要素に荷重 $P$ が作 用すると斜材の変形のため平行部材は接近する方向に変 位する，密実な部材に荷重が作用する場合，これとは逆 に平行な二面は離れる方向に変位する，したがってここ では $A_{b}$ の剛性を十分大きく取ることとし $X$ 軸方向の 変位を極力抑えて現実に近いものとする．支保工のピッ チを $t$ とすると

覆工の曲げ剛性 $I_{1}$ は

$I_{1}=t d^{3} / 12+(n-1) I_{s}$

ここに, $n:$ ヤング係数比

$I_{s}:$ 支保工の断面 2 次モーメント

格子枠要素の曲け剛性は, 単純曲げによっては斜材長 は変化しないので（図一7参照） $A_{a}$ のみによって決ま り

$I_{2}=(d / 2)^{2} \times A_{a} \times 2$

$I_{1}=I_{2}$ より

$A_{a}=t d / 6+2(n-1) I_{s} / d^{2}$

覆工の換算断面積は

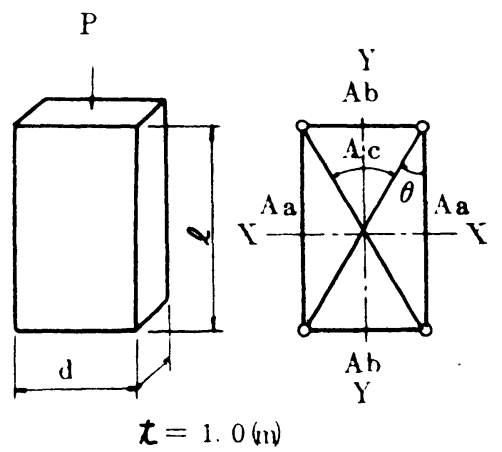

图一，徱工と格子枠棈造

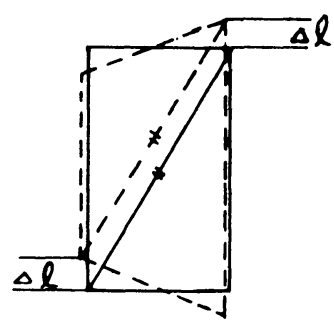

図一7 格子枠構造の単純曲げ

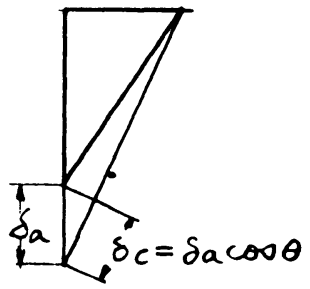

図一8 変位条件

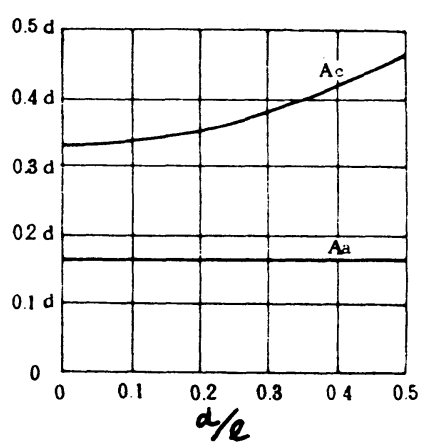

図一9 支保工なしの $A_{a}, A_{\mathrm{c}} \quad d / e$

$A_{1}=t d+(n-1) A_{s}$

$A_{s}:$ 支保工の断面積

各ロッド要素の軸力を $P_{a}, P_{b}, P_{c}$ とするとつり合 いより

$P=2\left(P_{a}+P_{c} \cos \theta\right)$

各ロッドの縮み量を $\delta_{a}, \delta_{b}, \delta_{c}$ とすると

$P_{a}=A_{a} E / l \times \delta_{a}$

$P_{c}=A_{c} E / l^{\prime} \times \delta_{c}=A_{c} E \cos \theta / l \times \delta_{c}$

一方变位の適合性より

$\delta_{c}=\delta_{a} \cos \theta$

式（15)を式（14）に代入すると

$P_{c}=A_{c} E \cos ^{2} \theta / l \times \delta_{a}$

式 (13)，(16)を式（12）に代入すると

$P / \delta_{a}=E / l\left(2 A_{a}+2 A_{c} \cos ^{3} \theta\right)$

すなわち, 格子枠要素の換算断面積は

$A_{2}=2 A_{a}+2 A_{c} \cos ^{3} \theta$

$A_{1}=A_{2}$ より

$A_{c}=\left\{t d+(n-1) A_{s}-2 A_{a}\right\} / 2 \cos ^{3} \theta$

支保工のない場合すなわち， $I_{s}=0, A_{s}=0$ のとき，

$A_{a}=t d / 6$.

$A_{c}=t d / 3\left|\sqrt{1+(d / l)^{2}}\right|^{3}$

このようにして定めた格子枠要素で覆工を表現して FEM で解析し，算出されたロッド軸力より覆工に作用 する軸力およびモーメントを求め, これより応力を算出 する.

（2）スリットのモデル化

鋼製支保T:に叮縮支保丁.を用い，吹付コンクリートに 


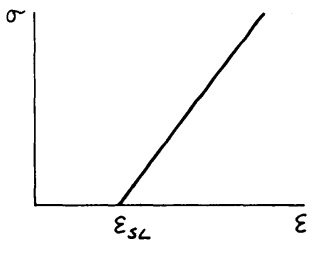

図一10 スリットモデル

幅 $20 \mathrm{~cm}$ 程度の吹付コンクリートのないスリット部分 を設けることにより支保全体に可縮性をもたせ，ある程 度変形を許して後に抵抗する工法があり, 膨張性地山等 大変形を生ずるトンネルに有効であると考えられてい る.このモデル化は次のような考えによって行う.スリッ 卜幅を $s$ とし, 吹付け長を $l$ とすると, $\varepsilon_{s l}=\sum s / \sum l$ はスリットを閉合するのに必要なひずみである．計算の 出発時点では吹付けコンクリートの剛性は 0 として計算 を行い, $\varepsilon \leqq \varepsilon_{s l}$ の範囲では引き続きコンクリートの剛性 は 0 として解析し, $\varepsilon>\varepsilon_{s l}$ になって後に吹付けコンク リートの剛性を導入する.すなわち図一10のように扱 う. 施工のある時点で吹付けコンクリートを追加して施 工し強制的にスリットを閉塞する場合には，計算上も同 じことができる.

\section{6. クリープと切羽進行による経時解析}

経時的応力, ひずみの変化の原因としてはまず地山の クリープによるものがあり，これを $\varepsilon_{\mathrm{c} 1}$ とする. 切羽が ほぼ一定速度で進行する場合, 切羽の進行に伴う三次元 的応力解放による変化も経日的変化とみなすことができ

る.これを $\varepsilon_{c 2}$ とする. 経日変化の合計は

$\varepsilon_{c}=\varepsilon_{c 1}+\varepsilon_{\mathrm{c} 2}$

$\varepsilon_{c 2}$ についてみると三次元解析あるいは地表沈下の実 測などによれば切羽通過時のひずみおよび沈下は最終量 の約 $30 \%$ であり，その後の変化はクリープ関数的であ る。したがって $\varepsilon_{c 1}$ ばかりでなく， $\varepsilon_{\mathrm{c} 2}$ もクリープ関数 を利用して表現することができる.

$$
\begin{aligned}
& \varepsilon_{C 1}=\alpha_{1} \varepsilon_{e}\left(1-e^{-\beta_{1} \cdot t}\right) \ldots \ldots \ldots \\
& \left.\varepsilon_{C 2}=\alpha_{2} \varepsilon_{e} \cdot F^{-\beta_{2} \cdot t}\right) \ldots \ldots . \\
& \varepsilon_{e}=\left[1+\alpha_{2}\left(1-e^{-\beta_{2} \cdot t}\right)\right] \varepsilon_{e \cdot F}
\end{aligned}
$$

$\varepsilon_{e \cdot F}$ は切羽での弾性ひずみ $\left(\varepsilon_{e}\right.$ at Face $)$ を, $\varepsilon_{e}$ は $\varepsilon_{e \cdot F}$ と遅れ弾性ひずみの合計を表わす。一般に $\beta_{2}>\beta_{1}$ であるから $\varepsilon_{c 2}$ が先に収歛するので式 $(22)$ を近似的に 式 (25)に置き換えることができる.

$\varepsilon_{C 1}=\alpha_{1}\left(1+\alpha_{2}\right) \varepsilon_{e \cdot F} \cdot\left(1-e^{-\beta_{1} \cdot t}\right)$.

前述のように $\varepsilon_{e \cdot F}$ は最終ひずみの約 $30 \%$ であるから $\varepsilon_{e \cdot F}=0.3\left(1+\alpha_{2}\right) \varepsilon_{e}$.

であり, $\alpha_{2} \fallingdotseq 2$ となる. $\varepsilon_{\boldsymbol{e} . F}$ を計算する際には地山の変 形係数は $\left(1+\alpha_{2}\right)$ 倍して, すなわち $3 D$ を用いる.
このとき支保の変形係数はそのままの值を用いる．支 保の固有の剛性に対し, 掘削に伴う強性変形が作用して 応力が発生するからである. 次のクリープ解析の段階で は, 各要素に強制ひずみが与えられるが,この際節点は 拘束されており，ひずみを打ち消すような節点力が算出 される.これを各節点ごとに合計すると不つり合い節点 力が発生する.この不つり合いの逆方向力を加えること により節点の拘束は解除される.この過程において地山 の変形係数は本来の值に戻されなければならない。 $\left(1+\alpha_{2}\right)$ 倍の変形係数に保っておくと節点力が過大に算 出される. また不つり合い節点力の分配の際にも地山と 支保で不均衝が生ずる.(以上の変換はプログラム上で 自動的になされる。

切羽進行に伴うひずみの進行は開孔直径 $a$ の 2 倍程 度進むとほぼ完了すると報告されている。いま $2 a$ 進行 した地点のひずみの進行度を $90 \%$ とすると，

$$
0.9=\left(1-e^{-\beta_{2} \cdot t}\right) \quad \therefore \beta_{2} \cdot t=2,3 \text {. }
$$

これより $2 a$ 進むに要する日数を予測すれば, $\beta_{2}$ を 定めることができる. 国鉄では断面，岩種，工法により 標準の進行を定めているが, NATM の場合も在来工法 と同程度の進行が出るとすると表一1のように断面と岩 種に応じて $\beta_{2}=0.2 \sim 0.8$ の範囲で定まる.

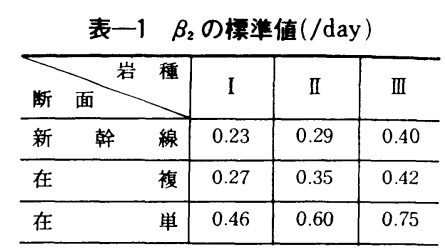

なお膨張性地山を除く一般地山では,クリープ的な性 質は少なく， $3 \alpha_{1} \ll \alpha_{2}$ であるから， $\alpha_{1}=0$ として $\alpha_{2}$ のみ によって経時解析を行っている.

なお切羽進行に伴う解析手法としては上記 (A とす る) のほかに下記の方法が提案されている.

B. 掘削相当外力を切羽の進行に合わせて分割して 除去する方法

C. 掘削部分の剛性を重ね合せた何枚かの要素に分 割してもたせ，切羽の進行に合わせて一枚ずつ除 去する方法 (要素重積法)

いずれの方法も本来三次元の問題を二次元解析で擬似 的に解こうとするものであるから，無理があり若干の欠 点を有する.

B の手法は部分掘削解析に欠点があると考えられる. たとえばベンチ工法の場合に，上半掘削相当外力を $100 \%$ 解放する前に下半を掘削することになり，上半掘 削相当外力を解放すべき節点が途中でなくなってしま う.このためには次の掘削ステップ直前で残りの掘削相 
当外力の全部を加える等の措置が必要となり, ベンチ長 の効果やインバートの早期開合効果を表わすのが難し い.

C の手法は, 仮定した変形曲線に適合させるために は試行的にこれら各要素の剛性を決めなければならな い. また部分掘削について B と同様の欠点を有してい る.

これに対し本プログラムで採用している．A の手法 の欠点は切羽で掘削相当外力を $100 \%$ 作用させているた め, その時点で地山応力は後方の収束した状態に近いも のになることである. しかしながら変位, 支保の応力等 はほぼ正しい值が得られるので実用上, 本手法が最も問 題が少ないものと考えている.

\section{7. 設計の流れ}

設計の全体的な流れを図一11に示す.地質については 岩種分類のほかに岩石三軸, 孔内載荷のような変形およ び強度に関する資料があることが望ましい，次に地表沈 下による地上構造物に対する影響が問題となる条件であ るかどうかを判断すべきである．ひるがえって，前者の 場合には調査も入念に行われなければならない，設計・ 施工法の選択にあたっては過去の事例を十分参考にすべ きであり, 地表沈下が問題となるトンネルではミニベン チ, サイロット，断面一次閉合等の早期閉合工法の採用 を検討する必要がある，モデル化は要素分割を行い, 覆 工要素の種類, ロックボルトの滑りを考慮するかどうか,

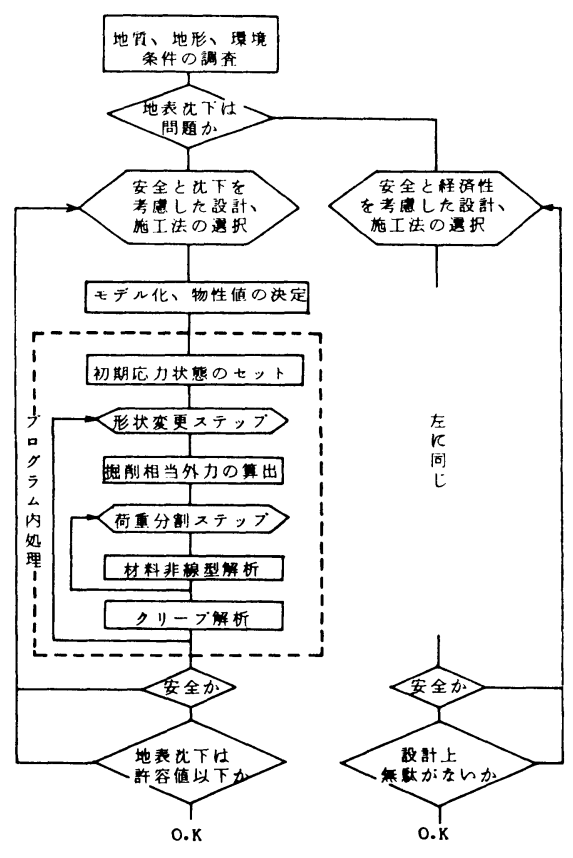

因一11 設計の流九
スリットの採用の有無等を選択し，解析ステップのタイ ミングを定める等である. 地山物性値は岩石試験の結果 が必ずしも地山全体を現わさず修正の必要な場合もあ り,この点の研究が必要である. 初期応力状態は自重解 析によりセットされる. 側圧係数 $K$ は平面ひずみ状態 を仮定すると $K=\nu /(1-\nu)$ であるが，一般にこの値は 最小值でありこれより大きいことが多い，この場合は データとして入力する. 形状変更ステップとは上半, 下 半など掘削による状態の変化をいう. 掘削の解析は, 掘 削部分を囲む節点において, 掘削する要素に作用してい る節点力（掘削する要素の応力に対する等価節点力）の 逆方向力を掘削相当外力として加え 0 とする方法によっ ている.このとき地山の変形係数は前節に述べたところ により，切端効果を反映させるために，便宜的に $\left(1+\alpha_{2}\right)$ 倍される. 外力は材料非線形性を考虑して数ステップに 分割して加えられ，增分法によって計算される．すなわ ち 1 ステップ前の応力状態での破壊接近度 $R$ から変形 係数, ポアソン比を定めこれによりひずみ増分を計算し 加算する方法である.クリープ解析はこのステップが全 部終了して後に, 必要なタイミングでなされる.まず全 節点を拘束し，クリープひずみを抑制することによる節 点不つり合い力を計算し, 次にこの不つり合い力の逆方 向力を節点外力として加える (このとき節点の拘束は解 かれる)。ロックボルトおよび吹付けコンクリートは掘 削後に施工され，切羽進行すなわちクリープ解析および 次段階以降の掘削解析で応力が発生する。この間ロック ボルトは滑りがチェックされる．滑りが発生するとその 節点における特殊結合要素のばね定数は 0 ( 0 に近い值) になり，その後の力の伝達はなくなる，それまでに発生 したボルト軸力はそのまま保持し，したがってボルトか ら地山への作用力も保持している.これは実験および現 場の観察においてボルトが滑ってからも補強効果を失っ ていないと判断され，それは粘着力および摩擦力による 力の伝達が引き続き行われていると考えられるからであ る. 吹付けコンクリートにおいてスリット要素を用いた 場合には閉合がチェックされ, 閉合後初めて応力が発生 する.このようにして 1 つの形状変更ステップが終了す ると次の形状変更ステップに進む. 格子枠要素を用いた 場合は部材軸力から断面力を求める必要があり,このた めに後処理プログラムが準備されている.

結果の判定は安全性と経済性の二面より行われる. 安 全性については次の諸点が検討される.
i）吹付けコンクリートの応力
ii ）ロックボルトの応力
iii）ロックボルトの安定性
iv）地山の破壊領域
v）内空変位量 
一般に，i），ii），iii）は主要因であり，iv），v) は補助要因であると考えられる。それは内空変位が大き く破壊領域が拡がったとしても応力が許容範囲内にあ り，ロックボルトが滑らないで安定していれば構造物と して安定していると考えられるからである.内空変位量 が大きくてもそれ自体は変形余裕量で対処できるもので あり絶対的なものではない，しかし変位量が大きくなれ ば，（）， ii ）， iii）の条件もすべて危険な方向に接近す ること, および応力および安定性の計測は困難であるの に対し変位計測は容易であることから, 変位量は危険予 知の重要な指標となる。 また土被りの浅い場合, 破壊領 域が地表までおよび非常に危険なことがある。主要因の うちロックボルトの安定性については，4（1）で述へ たごとく, 滑りが発生してもなお補強効果を発揮してい ることから，絶対的な不可の条件とはならないと考えら れる.実験によればボルトが一部で切れて後も，なお補 強効果をもっていることから, ボルト応力が降伏值を超 えても，仮設材としてはなお有効であると考えられる.

このような場合は最終的には吹付けコンクリートによっ て安全を確保することになる. しかし吹付けコンクリー トも条件によっては許容値あるいは仮設割增の許容值に すら入らない場合もあり，スリットが検討される．二次 覆工はこのような一次支保の忍力レベルによって必要の 有無および設計厚等が検討されるべきである.

経済性については, 極力吹付けコンクリート厚を小さ くし、ロックボルトは短く, 少なくするように検討され なければならない，一次支保の応力值がすべて許容値内 にあり, 安定している場合には二次覆工を省略すること も検討し得る.

しかし地表変位が問題になる場合は, 地表への影響度 合がすべてに優先する.

\section{8. あとがき}

本論文では 52 年より開発してきた NATM 設計用の プログラムの機能について報告した.

国鉄においては成田空港, 塩嶺, 宇佐美トンネル等で
用いられた。また部外へは受託の形で利用の便をはかり 横浜市地下鉄, 本四公団䉆羽山, 北海道開発局旭川卜ン ネル等の設計に適用している．また，日本鉄道技術協力 協会よりソウル市地下鉄 3,4 号線の都心部の NATM の設計を受託した。その中には島式フォームを有する二 柱式の 3 スパントンネルも含まれる.

本設計手法を用いるべき範囲は, 困難な場合と一般的 な場合には標準設計の検討等に利用するのがよいと考え る.

このように設計的な要素はほとんど取り入れ一応完成 したプログラムとなったが, 基本部, 細部の両面にわたっ て検討すべき点が多く, 今後の研究が必要であると考え られ，関係各位のご教示をお願いするところである.

なお, 入力値等使用上の具体的な問題点については引 き続き発表する予定である.

\section{参考文 献}

1）土屋敬・松本吉雄・川崎宏二：システムロックボルト の岩盤補強効果に関する基䃈的実験, 第 13 回岩盤力学に 関するシンポジウム講演論文集, pp. 96 99, 1980 年 2 月.

2）土屋 敬・安田憲彰・田沢雄二郎・須藤英明：大型卜ン ネル模型実験によるロックボルトの補強効果の㛟討，第 15 回岩盤力学に関するシンボジウム講演論文集, pp. 31 -34, 1982 年 2 月.

3）土屋 敬：NATM の設計について, 建機新報・土木七ミ ナーテキスト, 1979 年 4 月.

4）吉村 恒・土屋 敬：システムロックボルト設計プログ ラムの開発, 第 13 回岩盤力学に関するシンポジウム講演 論文集, pp. $81 \sim 84$.

5) 日比野敏・本島 睦：地盤材料の非線型な物性特性とを の数値表現, 第 17 回電力土木研究会資料, pp. 171 172, 1975 年 10 月.

6）生子幹雄・佐々木猛・杉本文男：岩盤，断層および破砕 帯の非線型な変形特性とその表現, 鹿島建設技術研究所 年報第 25 号, pp. 119 124.

7) 本島 睦・日比野敏・林 正史：岩盤堀削時の女定解析 のための電子計算ブログラムの開発, 電力中央研究報告 377012,1978 年 3 月.

(1983.8.31 • 受付) 